
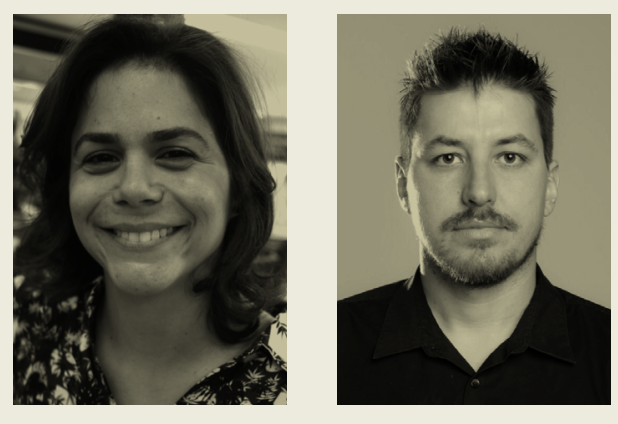

\title{
QUANDO HÁ POLÍTICOS NO CONSELHO DE ADMINISTRAÇÃO
}

Era de se esperar que escândalos como a Lava Jato afastassem o interesse das empresas em ter por perto profissionais ligados à arena política, no entanto a contratação de ex-integrantes do governo para compor conselhos de administração de empresas privadas vem se tornando cada vez mais comum no Brasil.

De acordo com estudo de Luiz Ecco, Rosilene Marcon, Ślvio Parodi Oliveira Camilo e Rodrigo Bandeira-de-Mello com uma amostra de 127 companhias de capital aberto em cinco setores, a quantidade de empresas que foram ao mercado capturar conselheiros conectados politicamente saltou de 38 em 1997 para 93 em 2008, ou seja, mais que duplicou. Segundo outro estudo, que está sendo realizado por Marina Gama, da Escola de Administração de Empresas de São Paulo, da Fundação Getulio Vargas (FGV EAESP), e Aline Gatignon, da Wharton Business School, em 2017, de 303 empresas de capital aberto, 241 - praticamente $80 \%$ - contavam com ao menos um conselheiro que já foi parlamentar, governante ou membro de alto escalão do governo (federal, estadual ou municipal).

Com a privatização e a criação de agências reguladoras, em 1997 cresceu o número de empresas no país que desenvolveram as chamadas estratégias de não mercado, contratando conselheiros politicamente conectados, hábeis em navegar pelos meandros da nova burocracia dos setores regulados. Com esses conselheiros, empresas esperam obter melhores informações sobre políticas públicas e acesso àqueles que desenham essas políticas.

Além disso, pesquisas mostram que um conselheiro politicamente conectado consegue auxiliar a empresa a entender quais os melhores caminhos a percorrer para conseguir aprovações de pautas importantes, como redução de impostos para determinada linha de produtos ou aumento de barreiras de importação de concorrentes, para se proteger de possíveis mudanças na legislação ou até mesmo para ajudar a antever o movimento dos políticos.

No entanto, uma estratégia como essa não necessariamente traz resultados econômicos superiores. As empresas que têm um conselheiro com background do mundo político até conseguem, com maior facilidade, obter financiamentos a longo prazo, mas estudos vêm mostrando que seu desempenho financeiro é pior em relação ao das empresas sem esse tipo de ligação, mesmo com a vantagem de terem um custo de capital inferior por conta do tipo de empréstimo a que têm acesso. Isso porque, em vez de maximizar o valor da firma, acabam por utilizar parte dos recursos para cultivar essas relações políticas, seja de forma legal, seja de forma ilegal.

Esse efeito negativo é menor em empresas com melhor governança, mostra estudo publicado neste ano no Journal of General Management, por Marina Gama, Gisele Walczak Galilea, Rodrigo Bandeira-de-Mello e Rosilene Marcon. A pesquisa considerou outro mecanismo usado pelas empresas em estratégias desse tipo, a doação para campanhas políticas, quando isso ainda era possível no Brasil, mas os resultados dão indícios de que qualquer forma de conexão política deve ser protegida por uma governança forte, que impeça atos ilegais, desvios em relação aos objetivos primordiais do negócio e prejuízos à sociedade. 